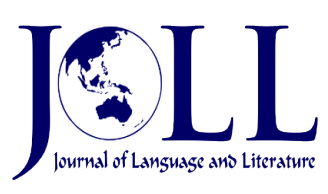

Vol. 21 No. 2, October 2021, pp. 318-327

DOI: 10.24071/joll.v21i2.3146

Available at https://e-journal.usd.ac.id/index.php/JOLL/index

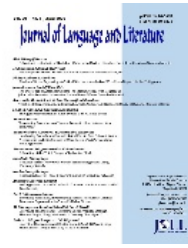

This work is licensed under a Creative Commons Attribution-ShareAlike 4.0 International License.

\title{
Women as Breadwinners in Maureen Sherry's Opening Belle
}

\author{
Margaretha Finna Calista \& Wening Udasmoro* \\ margaretha.finna@mail.ugm.ac.id \& udasmoro@ugm.ac.id \\ Faculty of Cultural Sciences, Universitas Gadjah Mada, INDONESIA
}

\begin{abstract}
There have been many popular fiction novels in the literature world that raise how women enter the economic aspect. One of them is the novel Opening Belle written by Maureen Sherry and published in 2016. Opening Belle represents women's participation in the financial sector because they want a good life. This research is studied with the feminist political economy theory proposed by Jacqui True. In her book, The Political Economy of Violence against Women, True explains that economic globalization has changed women's lives becoming financially independent. However, on the other hand, women involved in the public sphere are underappreciated and receive sexual harassment or violence, making it difficult for women to participate in the economic aspect. This research uses the descriptive qualitative method. With this method, the writer takes parts of the novel in the form of words, sentences, paragraphs which explain the economic aspect and women's participation in it. This research is analyzed through the explanations and utterances of the characters. The results of this study are: first, the participation of women as breadwinners in this novel is started as part of her life experiences and is driven by the hardships of her family; second, women are highly motivated figures so that they implement several strategies to survive in their office, namely by proving their competence, joining the GCC women's community and voicing equal rights in the workplace. In conclusions, economic globalization opens up women's opportunity to become the sole breadwinner in the family.
\end{abstract}

Keywords: Opening Belle; women's participation; Jacqui True

\section{Introduction}

In social life, women live inside two spheres, namely the domestic and the public sphere. The domestic sphere is known as activities or works within the household. Therefore, the domestic sphere is a sphere attached to women. Many factors construct the domestic sphere to be closely related to women. The domestic sphere also makes the women's image changing into second sex, which values women as inferior gender to men.

The most influential factor is the biological condition of women. The biological 
condition of women is a gift in human creation. Unfortunately, biological condition is also a factor that limits women's movement. Women's image is attached to the domestic because women's biological conditions are considered weaker than men.

Biological factors are the fundamental reasons why it is difficult for women to leave the domestic sphere. Women have burdens to bear, such as bearing children, raising them, caring for their families, taking care of health needs, doing housework, and so on (Moraletat, 2020, p. 8). In addition to these roles, women also experience menstrual cycles every month, making women considered as an irrational and less competent gender in society (Marçal, 2020, p. 32). Therefore, women are bound in the domestic sphere because society thinks that women's intellect and physical abilities are weaker than men (Nafiana, 2018, p. 4). This situation raises the question, what will happen if women try to enter the public sphere and succeed in maintaining their existence?

One aspect that encourages women to enter the public sphere is economic globalization. Economic globalization integrates the national economy into a global economic system (Agusalim \& Pohan, 2017, p. 104). The rapid development of economic globalization has many positive impacts on improving aspects, such as education, health, economic activities, social and cultural life (Yasmin, 2020). Economic globalization also opens up many new opportunities for women. The increase in various sectors has opened the space for women to move more freely. Nowadays, women have the opportunity to participate in the economic sector actively. Some women also become breadwinners in their families

However, the rapid development of economic globalization has not only had positive impacts. Negative impacts have also emerged, such as a stronger capitalist system. The capitalist system forms certain social classes. Women, especially working-class women, also feel the negative consequences. Working women are more vulnerable to the marginalization of a patriarchal culture in the exploitation of capital owners or family relationships (Wulansari, 2018). Besides, working women are often labelled as a form of "deviance" in the society because the ability to participate in the public sphere is a power belonging to men (Adichie, 2019, p. 49).

The issue of injustice that women get in the work environment is often raised as the topic of literary works. Literary work is a form of recording in the language conveyed to others (Metzger, 2016, pp. 20-21; Puspita, 2019, p. 30). Maureen Sherry is a fiction writer who has recorded traces of her experiences in a novel form. Based on personal experience while working as an employee at an investment bank in the United States, Sherry created Opening Belle published in 2016. This novel focuses on women in the United States who become the breadwinner in the family. Sherry describes how the working environment could be very intimidating, especially for women. Women need enourmous effort than men to be approved as competent workers.

The main character in this novel is Isabelle McElroy or Belle. Belle is a breadwinner for her family. She works at the Feagin Dixon Investment Bank. Her husband is unemployed, and she has three children. This novel's plot tells Belle's struggle to meet household needs, her three children's education cost, her husband's lifestyle, and paying off debts on her parents' house. As the sole breadwinner in her family, Belle works hard to pursue her goals for bonuses.

Nevertheless, as long as she worked at Feagin Dixon and held a relatively high position, Belle was still seen as a mother and woman rather than a competent senior employee. She was subjected to sexual, verbal and non-verbal harassment from her boss, deductions from wages and bonuses, and often belittled performance. Even her boss, King McPherson, publicly sexually abused Belle in front of male workers.

King is one of Belle's bosses, and he occupies an important position in Feagin Dixon. Therefore, Belle chooses to ignore his actions, considering that King has higher parts in Feagin Dixon. This situation is Sherry's description of how women are in a 
condition that is tied to the capitalist system. Women are often "locked up" in the system and cannot save themselves (Udasmoro, 2012). Based on this observation, the researchers determine the problems in this study, namely: first, how do women participate in being involved in their families' economic growth? Second, what are the strategies to enter the economic sphere?

An expert discussing this issue is Jacqui True in her book entitled The Political Economy of Violence against Women (2012). True said that as the economic sector develops, so does violence against women. Violence against women is a significant problem in all countries and worldwide, affecting women in every socioeconomic group and at every life stage (2012, p. 4). The violence experienced is not only limited to war areas or conflict zones. Even in peaceful situations, violence could still occur.

The rapidly developing economic globalization provides new opportunities and challenges for women. Women have the opportunity to work and become financially independent, but on the other hand, women have greater work demands than men. Women do not get equal rights with men. This also makes women vulnerable to violence that occurs (Udasmoro, 2017). Violence could occur when women breadwinners are considered as a threat to men's traditional roles. This could happen because women are rated as an inferior gender compared to men (Ikbal, 2020, p. 200). The traditional role of men as breadwinners is one of the masculine constructions that become a hegemony in the social environment. This construction forms the assumption that men are the primary producers, while women should be at home (Reed, 2020b, p. 27). If men cannot fulfil this role, men will look for other ways to maintain their masculinity. Some men choose to commit violence as a symbol of the masculinity that women are trying to replace. Violence by men defines as a response to women's more challenging demands for economic autonomy independence (Federici, 2020, p. 92; Kristen, Banuelos, \& Urban, 2015, p. 173).

Apart from physical violence, economic globalization has not fulfilled women's rights, especially the right to live a good and prosperous life. Poverty is also a form of violence (Federici, 2020, p. 95). Various factors influence the quality of the welfare of women who participate in the economic sector. One of them is that women are considered a cheaper labour force than men.

Moreover, the feminist economy political approach that True introduced in her book can be applied to this study's focus. Opening Belle is a novel that tells how women could be the sole breadwinners in the family and have more competent work skills than men. The main character, Belle, is also told as a woman who has a reasonably high position. Belle is a woman who financially independent without help from men. After leaving Feagin Dixon, Belle even opened a new financial office and recruited other female colleagues at the end of the story.

This study aims to explore women's participation as breadwinners in the novel Opening Belle by Maureen Sherry. This exploration activity is aimed to look at feminine strategies in the economic sector, which men dominate. This study also aims to provide a new perspective on feminism by analyzing women's participation in the economic aspect.

The researchers chose Sherry's novel, Opening Belle novel as a material object and True's feminist political economy theory as a formal object. Opening Belle's novel has never been reviewed, so that no relevant study could be included as a literature review. However, the researchers found several studies relevant to True's idea as the leading theory of this analysis.

The studies below are some of the research which used the feminist political economy as an approach. The studies focus on how women are vulnerable to violence, especially women who replace their husbands to become providers for their family. Unfortunately, the feminist political economy approach has never been applied to related literary studies, so that there is no literary study that could be included in the literature review. Nevertheless, these studies have the same significant problems with Belle's 
situation in Feagin Dixon; women have no equality and protection in the working world.

The first research is a dissertation by Melissa Frances Johnston (2018) entitled The Political Economy of Gender Interventions: Social Forces, Kinship, Violence, and Finance in Post-Conflict Timor Leste. This study's focus is the existence of gender intervention in Timor Leste so that there is a domination of the ruling class, namely the Liurai Dato class. Johnston concluded that the root problem of gender intervention in Timor Leste was the unequal structural relationship between class and gender (Johnston, 2018, p. 275). Gender intervention results in inequality of rights received by women, which affects women's welfare.

The second research is the article entitled Understanding Women's Experience of Violence and the Political Economy of Gender in Conflict: The Case of Syria written by Khuloud Alsaba and Anuj Kapilashrami (2016). This research concludes that based on an analysis of the conflict in Syria, there are three problems are happening (Alsaba \& Kapilashrami, 2016, p. 12), first, an environment full of fights and many ideological differences make women very vulnerable to violence. For this analysis, Alsaba and Kapilashrami provide examples of ISIS's abuses of slavery, especially for women; second, the risk and experience of women's violence is influenced by the intersection of class, ethnicity, and political activism, geography/place of residence, economy, and religion. Poverty is a decisive factor in increasing women's violence. Violence is committed by men when they become unproductive in economic aspects. Violence is an aggressive form of male power over women; third is Syrian women bound in political, social, and economic aspects. The relationship between these three aspects is detrimental to women through institutions such as religion and family, where women are prohibited from leaving the domestic sphere.

Furthermore, the third research is an essay written by Jacqui True herself, entitled A Tale of Two Feminisms in International Relations? Feminist Political Economy and the Women, Peace, and Security Agenda (2015). This essay describes a feminist political economy approach that analyzes men's analogy as the head household and the masculine state. True underlines her ideas about how the state supports male domination and masculine roles as providers in the family; therefore violence in the family continues. (2015, p. 422).

\section{Methodology}

This research is conducted in five steps. First, the researchers choose a focus for this study. In this case, the focus is on analyzing women's participation in the economic sphere. The second step is to select a literary work that is going to be analyzed. The third step is reading the novel deeply and create problem formulations related to the topic. The fourth step is to answer the problem formulations while applying the theory to the analysis. The last one is to conclude the result of the analysis.

The method used in this research is descriptive qualitative, containing data such as words, sentences and paragraphs related to the narrative of women's participation in the novel Opening Belle. The data obtained for this study through the explanations and sayings from the characters. This research is a literature study and uses a feminist political economy approach initiated by Jacqui True in her book The Political Economy of Violence against Women (2012). This theory is used to understand the relationship between women and their participation, especially in the economic aspects of Opening Belle.

\section{Results and Discussion}

Opening Belle offers an exciting take on woman's participation in the economy from the point of view of its main character, Belle. She experiences various kinds of skeptic perception from her male counterparts, indicating that its roots in the patriarchal system in modern society (J. True, 2012). Furthermore, she experiences sexual harassment and masculine domination even though she has already achieved her office's managerial position.

However, Belle challenges traditional women's domestic sphere role by employing specific strategies to keep her contribution to 
economic exchange stable. Such exchange of ideas and women emancipation in the economic sector is presented in the following discussions.

\section{The Stereotypes of Women as Breadwinners in the Work Environment}

Belle is a character created by Sherry, who represents women active in the public sphere as a breadwinner. Before she married her husband, Belle was already supporting her ex-boyfriend, Henry Wilkins. Belle's situation is originally formed because Belle worked earlier than Henry. Belle's accomplishments in Feagin Dixon's office were so high that it stretched her relationship with Henry. Henry has the principle that a breadwinner or doing business is a man's job. The following is the depiction of Sherry in her novel.

This money for teasing men." Henry had declared to me one day, as I proudly flashed a bonus check in front of him. Henry started acting like some portion of his manhood was being questioned by me. It was clear that Henry wanted to be a provider. The fact that I was out earning him made him nuts. (Sherry, 2016, p. 13)

In the end, Belle was abandoned by Henry. Later, Belle became involved with Bruce McElroy and married. The same situation was repeated because Bruce did not have a permanent job. Belle's income is higher than Bruce's, so that Belle becomes the breadwinner in her family. Unlike Henry, Bruce could accept these conditions.

Women's position as breadwinners is dominated by negative responses in this novel, both from fellow women and men. At Feagin Dixon, Belle is one of two successful women who reached her current position as a managing director (this would be later written as MD). It took Belle twelve years to work for her position as MD in maledominated environment.

Even though Belle has a reasonably high position in her office, she is not free from sexual harassment from male co-workers. They think that Belle's ability to compete with men is a threat to destabilize male masculinity. In social construction, men are obliged to be considered breadwinners, and therefore when there are women who can compete with that role, men take other ways to show their masculinity (Udasmoro, 2017). This is in line with what True (Kohli, 2015, p. 498) stated that on the one hand, the increased female literacy rate and the higher number of females in the workforce have made women capable of earning. Still, on the other hand, it has disturbed the traditional gender role of men as breadwinners.

Apart from Belle, other female characters in this novel have experienced the same thing, even worse. This because they do not have a position as high as Belle, so they feel like they do not have the strength to fight these acts of harassment. In this situation, women are more susceptible to get abused by men physically or mentally (Folke, Rickne, Tanaka, \& Tateishi, 2020). Therefore, the form of harassment or violence that often occurs in the work environment manifests male masculinity.

With this concept of manifestation, women as breadwinners often receive negative stereotypes. Women's competence is underestimated so that it could harm on women's careers. Also, women still do not have full rights in the work environment. They still suffer from unfavourable policies such as lower salaries, maternity leave, and under-appreciated work results. The author, Sherry, also represents this situation in her work.

Anyway, the old boys are a bit pissed at Fletch right now, Butler's awful, and without me there's nobody who actually transacts business between Feagin and T. Rowe Price so they've gone back to calling $m e$, which is fine and I'm still doing all the same stuff except Butler and Fletch get paid instead of me. (Sherry, 2016, p. 32)

"Have an abortion." "Wait. You were six months pregnant," Amy said. "Thomas was upset at the potential disruption of his own work. He started openly complaining about me, telling people that I kept running off for sonograms." (Sherry, 2016, p. 35) 
The data above is a situation that represents how women treated unfairly in the working environment. From the first citation, one of Belle's colleague who successfully manages to solve work-related problems does not get paid by Feagin Dixon. Instead, the male workers get the full salary. Here, women's effort in the public sphere does not get enough appreciation. This form of inequality is a manifestation of masculinity in working place. The construction of masculinity makes women become subordinate gender, making women more vulnerable to men's dominance.

The second citation represents how women are subordinate gender. As stated before, women's biological are influential aspects of masculinity construction. The bosses in Feagin Dixon asked one of the women employees to do an abortion. The bosses do not want to give maternity leave to avoid inefficient work result. Again, women have to face inequality treatments in the working environment. This situation is the cause of the construction of masculinity against feminine identities, activities, and institutions. The constructions are often targeting or affecting women (True, 2012, p. 42).

\section{Forms of Women's Participation in the opening Belle}

Belle's participation in the economic sphere began in 1990. Belle, who was currently in college, took several additional classes to support her studies. Belle is told that she wants to take an anthropology class in the novel but changes to a wine tasting class.

It turned out that wine tasting was offered as an elective in the School of Hotel Administration. According to Henry, knowing about wine was the most useful class the university offered. (Sherry, 2016, p. 83)

The above quote describes the situation when Belle finally decided to take a wine tasting class. The wine tasting class was considered helpful in the future because Belle realized that she needs to form broad relationships to support her work. Wine is a drink that is often served at every event, especially business meetings. For this reason, adding knowledge about good wine could be an additional value for Belle.

Belle's participation in the economic sphere was then continued after Belle finished college and was accepted to work at Feagin Dixon bank. In the novel, Belle must work immediately after graduating from college because her father is sick from cancer and her mother has debt for the house they lived in. Plus, her boyfriend, Henry, was still in college, so Belle also had to pay for their lives.

Belle started her career as a salesperson, where she had to find and convince customers to invest in or buy shares in certain companies. With the rapid growth of the global economy, especially in the United States, Belle's career has become more stable. Her achievement is also supported by her competence and work connections so that Belle eventually becomes financially independent.

However, being independent in the financial aspect does not necessarily make Belle feel that she is living well. The necessities of life, school fees, and paying off her parents' debt make Belle tied up in a vicious economic system. Belle's situation becomes a paradox. In the end, Belle no longer loved her job, but she was forced to do it because she needed money to support her family (Vida, Udasmoro, \& Noviani, 2020).

To keep the economy going, Belle eventually invested part of her savings in stocks. Sherry described Belle as a smart, conscientious woman and never act carelessly, with the result that Belle gets a big profit from the shares she chooses and gets a plus value in Feagin Dixon because she has succeeded in attracting many investors. The following quote is Belle's situation in the novel.

I was able to invest for myself and put quite a bit of our personal savings account into the stock. How much? I can't exactly remember but it was a lot. I can't breathe: 
it's a big car, it's a different nanny--or it's no nanny, it's sitting with the PA Ladies at preschool chapel, it's something close to $\$ 3$ million. . I scream, we're rich, we're rich! (Sherry, 2016, p. 107)

The quote above represents Belle has succeeded to gain profit from her investment. Since Belle is the only provider for this family, she has to manage her family financial. In order to maximize her salary, she put some of her funds into investment.

The forms of women's participation in this study started when Belle took wine class tasting to support her studies. After graduating from college, Belle has to participate actively in the economic sphere. She needs to be a provider for her family. As economic globalization has expanded, women have the same access as men to productive resources (True, 2012, p. 6). Globalization has created new opportunities for women to be financially independent. Thus, forms of Belle's participation in financial aspects are necessary to increase her family's finances.

\section{Women's Strategy in Economic Sphere}

Although Belle has actively participated in the economic sphere, Belle cannot avoid the negative stigmas constructed in her work environment that dominated by men. To guarantee her career and safety in the work environment, Belle applies at least three strategies during her work in the novel. First, she proves women's extraordinary competence in the public sphere; second, she joins the community of working women who experience the same struggle; and third, she opens her network with someone who dares to talk about women's rights in the work environment.

Belle's first strategy was self-evident. As previously explained, Belle is a woman who has a high position in Feagin Dixon. This position proves that women's competence deserves attention and appreciation, and women could flourish without being tied to biological factors. The biological condition of women is a factor that forms a negative stigma against women breadwinners (J. True, 2015). This happens because women are considered more inferior and powerless and depend on the superior male gender to support them and their children (Reed, 2020a, p. 4). Consequently, Belle and other female employees who are sexually harassed, received lower salaries, and difficulty obtaining maternity leave is a form of manmade law in a patriarchal society divided into social classes (Reed, 2020a, p. 5; J. True, 2012).

Although Belle's first strategy did not significantly impact her safety in the office, Belle managed to prove that she was a competent employee and could compete with the male employees. Tim Boylan, one of her clients, appreciated Belle's hard work, who opened her career path wider.

"Well, really, Ms. McElroy, I want you to know that I do remember my manners. The reason I'm here tonight is to personally thank you for probably the two best ideas in our portfolio, this CeeV and EBS. If this thing works out, you'll have made our year. Let me know when you want to come work for me!" He laughs (Sherry, 2016, p. 128)

This quote above represents the result of Belle's hard work. She gets appreciated by Tim Boylan, one of her essential clients, because she shows impressive competencies and skills in finding beneficial investment. Belle's situation proves that women could have the same abilities as men. Women need opportunities to prove their skills.

Belle's second strategy is to incorporate herself into the women's community formed secretly from the work environment. Although Belle had doubts that this community would affect his career, Belle did not deny that the inappropriate actions that male employees had against women were too far for her safety.

The Glass Ceiling Club (GCC) is the name of a community of several female employees at Feagin Dixon formed to share complaints about unfair treatment in the office. Belle is a member of the community. The GCC regularly holds lunches together to discuss how to improve a conducive work environment for 
women. Finally, they appointed Belle to be the speaker who represents their problem. Although the existence of GCC becomes backfired for them (there were several female employees dismissed and Belle was forced to train a new male assistant to replace her), in the end, GCC managed to convince Belle that a cultural change in the work environment was needed (Fatimah, 2019).

Based on Sherry's description in her novel, Feagin Dixon is a working place that shows inequality treatments between men and women employees. True emphasizes that a globalized economy is one factor that makes women vulnerable to violence, especially some groups of women $(2012$, p. 9). Thus, the existence of GCC is significant to Belle's effort to make a safe working environment.

The last strategy is the development of Belle's character. At first, Belle was told as a competent employee but chose to remain silent when she was harassed by King, one of her bosses. After being involved with GCC and Kathryn, one of the employees who also experienced unfair treatment, Belle becomes more courageous in voicing women's rights in her work environment.

"Look, when I was pregnant here," I start to softly explain, "I would cover my stomach when someone downstairs dropped too many f-bombs on me. I had to laugh with King when he mooed at the sight of my breast pump. I ignored the time someone taped torn panties on my screen when I came back from my honeymoon. I'm just depleted from all of this. I don't want to hear slut jokes all day long. I don't want to work in a frat house. I want to be paid equally. I want my input on abnormal rates of risk we take to be heard. I want this place to live up to its potential". (Sherry, 2016, p. 206)

The quote above is when Belle first opened her voice on women's unfulfilled rights in Feagin Dixon. Belle's action is considered quite brave because Feagin Dixon is not used to women's active participation. In the end, Belle's efforts were ignored by Gruss, one of the bosses at Feagin Dixon. Other women invited to speak at Gruss's forum chose to remain silent for fear of losing their jobs. Belle finally realized that Feagin Dixon's environment was too dominated by male power and capitalism so that women become submissive and choose to remain silent. However, what Belle has done inspires other employees to act braver in protecting themselves in the work environment.

At the end of the story, Feagin Dixon was declared bankrupt due to the United States' financial crisis. Belle also decided to leave Feagin Dixon and form a new office where all the workers are members of the GCC community. Belle and the GCC women agreed to work together and build a new place, namely Arbella Financial, where their hard work will always be appreciated without fear of sexual harassment or improper salaries. They are also committed to rescuing other female workers in Feagin Dixon who has suffered a similar fate.

We started this place with settlement money the GCC received. Manchester Bank set aside money for pending Feagin Dixon lawsuits. Once they got to know the firm they bought, they foresaw litigation raining from the sky regarding shady mortgages, extreme financial instruments, and, where the GCC came in, harassment and unfair pay practices. (Sherry, 2016, p. 338)

In Opening Belle novel, women are considered as the gender that is not capable of participating in the public sphere as employees in the working environment. Women have to face sustainable unsafe working experiences and do not get appreciated enough. Belle's attempt to apply three strategies into her working experience represents women's struggle to reach gender equality.

\section{Conclusion}

Like the character in Sherry's novel, Belle represents women who are active in the economic sphere. One of the main reasons women decide to be actively involved is the pressure from the family economy. Belle's situation required her to be the sole breadwinner in her family. She also had to 
replace her father's position to pay off her parents' house debt. Therefore, Belle's decision to start her career at Feagin Dixon was a form of economic participation depicted in the novel Opening Belle.

In her work environment that men dominate, Belle is a highly motivated character who never gives up. She also strives to promote female workers' equality in her office to have the same rights as male coworkers. Belle's strategies prove her work competence through her position, joining the GCC women's community, and voicing their rights in the forum at Feagin Dixon.

Belle's role as a breadwinner is women's participation in the public sphere which is closely related to economic globalization's enormity. Economic globalization gives women the opportunity to become more independent, especially in the financial aspect. With high motivation, women could become the sole breadwinner in the family.

\section{References}

Adichie, C. N. (2019). A Feminist Manifesto Kita Semua Harus Menjadi Feminis (W. A, Trans.). Yogyakarta: Odysee.

Agusalim, L., \& Pohan, F. S. (2017, October 27). Globalisasi ekonomi dan pengaruhnya terhadap kemiskinan dan ketimpangan pendapatan di indonesia. 103-119. Yogyakarta: Universitas Atma Jaya. https://doi.org/10.5281/zenodo.103761 8

Alsaba, K., \& Kapilashrami, A. (2016). Understanding women's experience of violence and the political economy of gender in conflict: The case of Syria. Reproductive Health Matters, 24(47), 517. https://doi.org/10.1016/j.rhm.2016.05.0 02

Fatimah, D. (2019). They, the Brave: Narratives of Women's Agency in the Peasant Movement in Wongsorejo, Banyuwangi. In W. Udasmoro \& A.
Rahmawati (Series Eds.), Gender and Peacebuilding: Agency and Strategy from the Grass Root (pp. 1-17). Yogyakarta: Universitas Gadjah Mada, Faculty of Cultural Sciences.

Federici, S. (2020). Perempuan dan Perburuan Penyihir (L. Sudiono \& N. Zega, Trans.). Yogyakarta: Penerbit Independen. Retrieved from https://penerbitindependen.com/produc t/akan-terbit-perempuan-danperburuan-penyihir-silvia-federici/

Folke, O., Rickne, J., Tanaka, S., \& Tateishi, Y. (2020). Sexual Harassment of Women Leaders. Daedalus, 149(1), 180-197. Retrieved from https://www.jstor.org/stable/48563040

Ikbal, M. (2020). Kekerasan terhadap Perempuan dalam Novel Entrok Karya Okky Madasari. In W. Udasmoro \& W. Nayati (Eds.), Interseksi gender perspektif multidimensional terhadap diri, tubuh, dan seksualitas dalam kajian sastra (pp. 198-207). Yogyakarta: Gadjah Mada University Press.

Johnston, M. F. (2018). The political economy of gender interventions: Social forces, kinship, violence, and finance in postconflict Timor-Leste (Master Thesis). Murdoch University, Australia.

Kohli, A. (2015). The Political Economy of Violence Against Women by True, Jacqui. Journal of Women, Politics \& Policy, 36(4), 498-500. https://doi.org/10.1080/1554477X.201 5.1083738

Kristen, E., Banuelos, B., \& Urban, D. (2015). Workplace Violence and Harassment of Low-Wage Workers. Berkeley Journal of Employment and Labor Law, 36(1), 169$204 . \quad$ Retrieved from https://www.jstor.org/stable/43551801

Marçal, K. (2020). Siapa yang Memasak Makan Malam Adam Smith? (N. D. Andarnuswari, Trans.). Tangerang Selatan: Marjin Kiri.

Metzger, M. J. (2016). Epistemic Injustice and "The Rape of Lucrece." Mosaic: An Interdisciplinary Critical Journal, 49(2), 19-34. JSTOR. Retrieved from http://www.jstor.org/stable/44030582

Moraletat, E. (2020). Perempuan Negara dan Keluarga (Heterotopia, Trans.). Yogyakarta: Penerbit Liberta. 
Nafiana, F. I. (2018). Paradoksalitas Pemosisian Perempuan antara Ranah Publik dan Domestik dalam Novel-Novel Suparto Brata: Ser! Randha Cocak, dan Nona Sekretaris. In W. Udasmoro (Ed.), Dari Doing ke Undoing Gender: Teori Dan Praktik Dalam Kajian Feminisme (pp. 218). Yogyakarta: UGM Press.

Puspita, Y. (2019). Stereotip Terhadap Perempuan dalam Novel-Novel Karya Abidah El Khalieqy: Tinjauan Sastra Feminis. Ksatra: Jurnal Kajian Bahasa dan Sastra, 1(1), 29-42. https://doi.org/10.1983/ksatra.v1i1.7

Reed, E. (2020a). Apakah Takdir Perempuan Sebagai Manusia Kelas Dua? (S. N. Dewi, Trans.). Yogyakarta: Penerbit Independen.

Reed, E. (2020b). Mitos Inferioritas Perempuan (D. Mahardika, Trans.). Yogyakarta: Penerbit Independen.

Sherry, M. (2016). Opening Belle. New York: Simon \& Schuster.

True, J. (2012). The political economy of violence against women. New York, NY: Oxford University Press.

True, J. (2015). A tale of two feminisms in international relations? Feminist political economy and the women, peace and security agenda. Politics \& Gender, 11(2), 419-424.

https://doi.org/10.1017/S1743923X150 00136

Udasmoro, W. (2012). Konsep Nasionalisme Dan Hak Reproduksi Perempuan: Analisis
Gender Terhadap Program Keluarga Berencana Di Indonesia. Jurnal Humaniora, 16(2), 147-154.

https://doi.org/10.22146/jh.814

Udasmoro, W. (2017). Reproduksi Womanhood dalam Novel Bunda: Kisah Cinta 2 Kodi Karya Asma Nadia. Adabiyyāt: Jurnal Bahasa dan Sastra, 1(2), 182-200. https://doi.org/10.14421/ajbs.2017.012 03

Vida, H. D., Udasmoro, W., \& Noviani, R. (2020). Women's Resistance towards "Master Narratives" through Female Travelers' Instagram. KnE Social Sciences, 22-30-22-30. https://doi.org/10.18502/kss.v4i10.738 8

Wulansari, A. D. (2018, April 21). Beban Ganda dan Komodifikasi Perempuan dalam Kapitalisme. Retrieved January 21, 2021, from MAP Corner-Klub MKP UGM website:

https://mapcorner.wg.ugm.ac.id/2018/0 4/beban-ganda-dan-komodifikasiperempuan-dalam-kapitalisme/

Yasmin, P. (2020). Dampak Positif dan Negatif Globalisasi di Berbagai Bidang Lengkap. Retrieved January 21, 2021, from Detiknews website: https://news.detik.com/berita/d5252353/dampak-positif-dan-negatifglobalisasi-di-berbagai-bidang-lengkap 